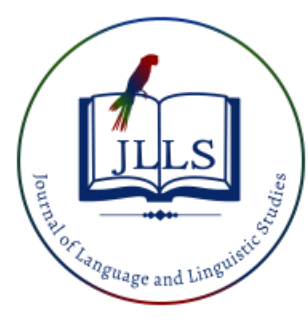

Available online at www.jlls.org

JOURNAL OF LANGUAGE AND LINGUISTIC STUDIES

ISSN: $1305-578 \mathrm{X}$

Journal of Language and Linguistic Studies, 16(3), 1594-1610; 2020

\title{
Systemic functional linguistics-legal genres and their configurations in the Islamic law and jurisprudence textbooks at a university in Indonesia
}

\author{
Issra Pramoolsook $^{a}$ iD, Ahmad Amin Dalimunte ${ }^{\text {b } 1 \text { iD }}$ \\ ${ }^{a}$ Suranaree University of Technology, Suranaree, Thailand \\ ${ }^{b}$ Universitas Islam Negeri Sumatera Utara, Medan, Indonesia
}

\section{APA Citation:}

Dalimunte, A.A., \& Pramoolsook, I., (2020). Systemic functional linguistics-legal genres and their configurations in the textbooks of Islamic law and jurisprudence at a university in Indonesia. Journal of Language and Linguistic Studies, 16(3), 1594-1610.

Submission Date: 26/6/2020

Acceptance Date:. 26/8/2020

\begin{abstract}
The great importance of textbooks in the English language in the academic, pedagogic, and scientific world is uncontested. Acquiring holistic knowledge of legal transdisciplinary is of great importance to Islamic law students in Indonesia. Nevertheless, English reading proficiency of Indonesian students is problematic. The present research was to identify the genre types and unfold them through what patterns the genres are mostly structured. Data of the study were one Islamic law textbook and one jurisprudence textbook used as teaching resources and required reading at Universitas Islam Negeri Sumatera Utara, Indonesia. Based on the five main Systemic functional linguistics-based genre frameworks for the analysis, findings from the Islamic law textbook showed 18 genre types including three proposed ones under four genre families of which History genres are the most frequent ones followed by Explanation, Report, and Argument genres. On the other hand, 16 genre types including three new ones belonging to four genre families were identified in the jurisprudence in which Report genres are the most frequent ones followed by Argument, Explanation, and History genres. The commonalities and discrepancies of the findings between the two legal textbooks are assumed to be the logical results of the ideological differences and the resource aspects from which the legal discipline is oriented. The findings of the study would be useful to design teaching of reading legal English texts that can facilitate students which is unfortunately neglected by both English and law teachers.
\end{abstract}

(C) 2020 JLLS and the Authors - Published by JLLS.

Keywords: systemic functional linguistics; genre; textbook; islamic law; jurisprudence

\footnotetext{
${ }^{1}$ Corresponding author. Tel.: +62 82170369807

E-mail address: amindalimunte@ uinsu.ac.id
} 


\section{Introduction}

Textbooks play significant roles in education. Past investigations showed that they very prominently compose and guide instructions (Elliot and Woodward, 1990; Stern \& Roseman, 2004). They deliver information and knowledge and are one of important mediums where ideas and analytical techniques in subject fields are portrayed. Through textbooks, learners are able to access various types of disciplinary knowledge (UNESCO, 2009), and they can find models of scientific texts in the textbooks that they read (Martin, 1993; Hyland, 2000). In addition to developing reading and writing skills, textbooks also encourage students to think critically and creatively, and to learn autonomously (UNESCO, 2009).

In spite of having crucial roles and important pedagogical objectives that are necessary to be realized, textbooks are difficult for learners to read. Text structures on which the texts are constructed (Strong et al, 2002) are claimed to be one of the adversities (Lee \& Spratley, 2010). Uso-Juan and Flor (2006) referred to this issue as formal schema that is learners' knowledge about the patterns of the texts so that they can perform top-down processing, such as predicting and inferencing. Their formal schema is beneficial to facilitate them to predict main and supporting ideas, and to make meaning of the texts as well. Knowledge of the text patterns has been much investigated and is considered beneficial to facilitate learners to distinguish between important and less important information as well as the text organization and information recall (Leon \& Carretero, 1995). The knowledge deals with an understanding of the overall organization and top-level text structure. Thus, the lack of formal schema is claimed as one of factors leading to reading comprehension problems. Many past investigations have also shown that the awareness of text structures is an effective reading strategy for improving reading comprehension and information recall (Meyer, 1975; McGee, 1982; Carrell, 1985, 1992; Richgels et al, 1987; Dickson, 1999; Zhang, 2008; Zarrati, Nambiar, \& Maasum, 2014).

Therefore, if the generic structures of the text can be configured, the problems can be solved. The disclosure of legal text structures as the key purpose of this research was to be achieved by examining the generic structure through which the legal texts are composed. In spite of the given textbooks' significance, Hyland (2000) asserted that they are disregarded, and knowledge about their rhetorical patterns, their connection to other genres, and their variations across different disciplines are little. For students of Islamic-oriented universities, such as Universitas Islam Negeri Sumatera Utara (UINSU) having the holistic transdisciplinary views and knowledge in particular subjects, such as Law based on various approaches and principles either Islamic or non-Islamic is considered crucial. The researchers assume that the text structures of the same discipline but is governed by two different ideologies and approaches, or originate from two different disciplinary resources could be different. The textbooks in use as part of the disciplinary pedagogy may not be the same in terms of the genres used and the generic structure. Therefore, they may merit to be compared in this present research.

\subsection{Literature review}

To date, no effort has been found to unfold the way legal texts within university textbooks are constructed in order to make the texts accessible to learners. Past investigations, indeed, dealt with how language is used in various types of discourse including legal discourse. Vass (2017) analyzed legal texts in terms of how hedging was used through lexical verbs throughout three different kinds of text: law research article, majority opinion and dissenting opinion of the Supreme Court. Four different kinds of lexical verb hedges were compared: speculative, quotative, sensorial, and deductive. The results showed that quotative (argue) and deductive verbs (conclude) were used more frequently in the majority and dissenting opinions of the Supreme Court. Vass (2017) claimed that through quotative verbs, the legal writers justified their claims on the ground of the statements or reports of others whereas through deductive verbs, the writers signaled how conclusions were achieved on logical basis. On the other hand, 
speculative (e.g. suggest, indicate, and believe) and sensorial verbs (e.g. seem and appear) were used more often in legal research articles. Through the speculative, the writers speculated about truth through legal opinions. By using the sensorial, the impressions that a person or an object has given were shown. Unsworth (1995) examined Explanation genre variations as well as their linguistic variations within science textbooks in primary and secondary schools. The findings showed that schematic structure of the genres was Orientation ^ Implication/Deduction Sequences ${ }^{\wedge}$ Closure. However, the generated structure was potential in the way that each of the stages had several variations. Orientation, for example, could be expressed by Phenomenon Identification, Phenomenon Background or Explanation Preview. The same thing also applied to the middle stage, Implication/Deduction Sequences, and the final stage, Closure. The Implication/Deduction Sequences was realized by varied stages, such as Conditions ${ }^{\wedge}$ Trigger ${ }^{\wedge}$ Transformation. The Closure stage was also realized by several stages, such as Conclusion, Extension and Elaboration.

The above review might indicate that there was no past investigation devoted to disclosing and comparing the ways that legal texts under two different ideological orientations, paradigms, or approaches are structured. This present investigation can be regarded as an initial attempt to categorize genre types and reveal the generic structures of legal texts, and to find out similarities and differences between the two university textbooks of Islamic Law and Jurisprudence.

\subsection{Research questions}

This present research put forward three crucial inquiries:

1- What are genres and their generic structures in the English language textbook of Islamic Law used in UIN-SU, Indonesia?

2- What are genres and their generic structures in the English language textbook of Jurisprudence used in UIN-SU?

3- What are the similarities and differences in terms of the genres and the generic structures used in the textbook of Islamic Law and that of Jurisprudence?

\section{Method}

\subsection{Data}

The data consisted of two target textbooks under the main discipline of Law. One deals with the field of Islamic Law (Shari'a Law) which is also referred to as Islamic Jurisprudence and the other is Law which is also known as Jurisprudence. These two textbooks were recommended by teachers in Law Departments under Faculty of Shari'a and Law at UIN-SU, Indonesia to be the data of the present study due to several benefits which cannot be found within the existing legal literature in Bahasa Indonesia. First, the textbooks' contents are richer and deeper through which learners can enrich and extend their disciplinary knowledge. Second, through the English language used, they can improve their familiarity with disciplinary terminologies. Third, the given textbooks deliver the contents that are more recent by which learners can rejuvenate their knowledge. Teachers can also take advantage of using the given textbooks in the English language for their professional progress by writing up recent themes and updated issued that have not been discussed in the existing legal literature.

The first legal textbook entitled An Introduction to Islamic Law was authored in 2009 by Wael B. Hallaq, James McGill Professor of Islamic Law at McGill University, Canada. It consists of 10 chapters throughout 29 sections and 200 pages with 84,632 running words. The second legal textbook entitled Essential Jurisprudence was authored in 2000 by Austin Chinhengo, a senior lecturer in Swansea Law 
School of Swansea University, UK. It was written in 7 chapters throughout 31 sections and 128 pages with 43,397 running words. It is considered useful for the law students since it covers basic legal subject matters and is presented in a simple and straightforward way. The textbooks were available both in hard copy and electronic format. Yet, for the sake of convenience in doing the analysis of the texts, the researchers used the hard copy ones.

\subsection{Analysis frameworks and procedures}

A very significant attention to reveal the structure of the text in science books was mainly conducted at the school level through the approach of Systemic Functional Linguistics (SFL). The selection of SFL genre frameworks as the analysis framework of this research is because the SFL approach is regarded to fit the nature and the characteristics of the textbooks themselves that were the data of the present research: the social purpose of textbooks and their material contents conveyed in the entire texts (Field), the way of how the texts were structured through written language (Mode), and the readers to whom textbooks are addressed to (Tenor). The genre frameworks below were also confirmed to be sufficiently workable by SFL scholars (Dalimunte \& Issra, 2020) to identify genre and deconstruct their generic structures in many texts in various science subjects. Genre refers to text types presenting the purposes of the texts and various subject matter-related contents or themes. Their purposes are achieved by several stages serving as opening, middle, and last paragraphs of the text. The stages comprehensively construct a particular pattern (structure). Recursive patterns found in different texts are termed by SFL scholars as generic structure.

Explanation genres mainly explain any events happened on causal basis.

Table 1. Analysis framework of explanation genres adopted from veel (1997), martin \& rose (2008), and derewianka \& jones (2012)

\begin{tabular}{ll}
\hline \multicolumn{1}{c}{ Explanation Genres } & \multicolumn{1}{c}{ Generic Structure } \\
Sequential Explanation & Phenomenon Identification $\wedge$ Explanation Sequence \\
Causal Explanation & Phenomenon Identification $\wedge$ Explanations \\
Factorial Explanation & Phenomenon Identification $\wedge$ Factors \\
Theoretical Explanation & Statement of Theory $\wedge$ Elaborations \\
Conditional Explanation & Phenomenon Identification $^{\wedge}$ Explanations \\
Consequential Explanation & Input $^{\wedge}$ Consequences $\wedge$ Reinforcement of Consequences \\
Cyclical Explanation & Phenomenon Identification $\wedge$ Explanations \\
System Explanation & Phenomenon Identification $\wedge$ Explanations \\
\hline
\end{tabular}

Report genres primarily classify and describe the characteristics of things.

Table 2. Analysis framework of report genres adopted from martin \& rose (2008), rose (2012), and derewianka $\&$ jones (2012)

\begin{tabular}{|c|c|}
\hline Report Genres & Generic Structure \\
\hline Descriptive Report & Classification $^{\wedge}$ Description \\
\hline Classifying Report & Classification $^{\wedge}$ Types \\
\hline Compositional Report & Classification ${ }^{\wedge}$ Components \\
\hline Comparative Report & Classification ^ Description \\
\hline
\end{tabular}

History genres mainly record the episodes and features of historical events and things according to particular viewpoints. 
Table 3. Analysis framework of history genres adopted from coffin (1997; 2006), christie \& derewianka (2010), and (derewianka \& jones, 2012)

\begin{tabular}{ll}
\hline \multicolumn{1}{c}{ History Genres } & \multicolumn{1}{c}{ Generic Structure } \\
Historical Recount & Background $^{\wedge}$ Record of Events $\wedge$ (Deduction) \\
Historical Account & Background $\wedge$ Account Sequence $\wedge$ (Deduction) \\
Historical Report & Identification $^{\wedge}$ Descriptions \\
Historical Site Studies & Site Identification $\wedge$ Site Descriptions \\
Period Studies & Period Identification $\wedge$ Period Descriptions \\
Biography & Person Identification $\wedge$ Episodes $\wedge$ Evaluation $)$ \\
\hline
\end{tabular}

Argument genres argue for or against any given issues in order to persuade readers.

Table 4. Analysis framework of argument genres adopted from coffin (1997; 2006), and christie \& derewianka (2010)

\begin{tabular}{ll}
\hline \multicolumn{1}{c}{ Argument Genres } & Generic Structure \\
Exposition & $(\text { Background })^{\wedge}$ Thesis $\wedge$ Arguments $\wedge$ Reinforcement of thesis \\
Discussion & $(\text { Background })^{\wedge}$ Issues $\wedge$ Perspectives $\wedge$ Position. \\
Challenge genre & Challenged Position $\wedge$ Rebuttal Argument $\wedge$ Antithesis \\
\hline
\end{tabular}

Response genres primarily interpret and judge other texts.

Table 5. Analysis framework of response genres adopted from christie \& derewianka (2010)

\begin{tabular}{|c|c|}
\hline Response Genres & Generic Structure \\
\hline Personal Response & Response ${ }^{\wedge}$ Observation \\
\hline Review & Context $^{\wedge}$ Text Description $^{\wedge}$ Text Judgement \\
\hline Character Analysis & $\begin{array}{l}\text { Character Presentation } \wedge \text { Character Description } \wedge \text { Character } \\
\text { Judgement }\end{array}$ \\
\hline Thematic Interpretation & Theme Identification $\wedge^{\wedge}$ Element Evaluation ${ }^{\wedge}$ Theme Reaffirmation \\
\hline
\end{tabular}

The analysis was conducted in three phases: 1) decoding and making sense of each sentence and paragraph, 2) conceiving any functions conveyed by the sentences or paragraphs and labeling those functions with any precise stages based on the genre models used in the analysis frameworks, and 3) comprehending how one stage is composed with the other stages which all together ultimately form a structure within the text and present a certain genre type. In this step, the analysis can be back and forth (D. Rose, Personal communication, July, 2017).

\subsection{Reliability of the analysis}

The reliability of the present analysis was significantly achieved through confirming the results between two coders, the researcher of the present study and an SFL professor with 30 years of academic experience, without any collaboration. Each of them independently coded 30 sections $(50 \%)$ of the whole textbooks. Section refers to the number of passages within the textbooks. Then, they sat together to check the coding. Many labels were similar yet a few discrepancies also happened. The inter-rater reliability was counted through percent agreement by which the number of coding agreement between the two coders was divided by the whole coding. The result showed that the percentage of genre types was $88.5 \%$ whereas the percentage of the stages was $88.7 \%$. According to Orwin (1994), more than $75 \%$ of reliability, $\mathrm{y}$ is considered excellent. Thus, in this present research, the obtained numbers were regarded sufficiently credible. 
To improve the reliability, a discourse-based interview was conducted with one specialist informant from the main discipline of Law to support the generated findings. He is a legal teacher with more than 20 years of experience in both Islamic Law and Law subjects at Shari'a and Law Department of UINSU. He was selected mainly for using the textbooks to teach the subjects and also recommended them to be data of the research. Considering the specialist is a non-English native and also for the sake of their convenience, the interview was conducted in the Indonesian language and in a casual way by approaching him on informal basis. The interview length was around 20-30 mins. A set of questions based on interesting findings from the analysis was prepared before the interview.

\section{Results and discussion}

Research question 1: what are the genres and their generic structures in the English language textbook of Islamic Law used in UIN-SU, Indonesia?

Table 6 shows 15 genre types configured by their generic structures found within the English language textbook of Islamic Law. The stages inside the brackets are referred to the optional ones. Number in the total column is the incidence rate of any given genre within the examined passages of the textbooks.

Table 6. The recognized genres and their generic structures within the textbook of islamic law

\begin{tabular}{|c|c|c|c|c|}
\hline No. & Genres & Generic Structures & Total & $\%$ \\
\hline 1 & Historical Report & Identification $\wedge^{\wedge}$ Descriptions & 29 & 24 \\
\hline 2 & Causal Explanation & Phenomenon Identification $\wedge^{\wedge}$ Explanations & 22 & 18 \\
\hline 3 & Historical Account & Background $^{\wedge}$ Account Sequence $\wedge$ (Deduction) & 16 & 13.2 \\
\hline 4 & Factorial Explanation & Phenomenon Identification $\wedge$ Factors & 9 & 7.4 \\
\hline 5 & Descriptive Report & Classification $^{\wedge}$ Descriptions & 7 & 6 \\
\hline 6 & Classifying Report & Classification $^{\wedge}$ Types & 4 & 3.3 \\
\hline 7 & Sequential Explanation & Phenomenon Identification ${ }^{\wedge}$ Explanations & 4 & 3.3 \\
\hline 8 & Consequential Explanation & Input $^{\wedge}$ Consequences & 4 & 3.3 \\
\hline 9 & Exposition & $\begin{array}{l}(\text { Background })^{\wedge} \text { Thesis } \wedge \text { Arguments } \wedge \text { Reinforcement } \\
\text { of Thesis }\end{array}$ & 4 & 3.3 \\
\hline 10 & Comparative Report & Classification $\wedge$ Descriptions & 3 & 2.5 \\
\hline 11 & Conditional Explanation & Phenomenon Identification ${ }^{\wedge}$ Conditions & 2 & 1.6 \\
\hline 12 & Discussion & Issue $^{\wedge}$ Perspectives $\wedge$ Position & 2 & 1.6 \\
\hline 13 & Theoretical Explanation & Statement of Theory $\wedge$ Elaborations & 2 & 1.6 \\
\hline 14 & Challenge & $\begin{array}{l}\text { Challenged Position } \wedge \text { Rebuttal Arguments } \wedge \text { Anti- } \\
\text { thesis }\end{array}$ & 1 & 0.8 \\
\hline 15 & Biography & Person Identification $\wedge^{\wedge}$ Episodes & 1 & 0.8 \\
\hline
\end{tabular}

Historical Report is the most frequent genre within the Islamic Law textbook which encompasses $24 \%$ of the overall genres. Its generic structure is similar to Coffin (1997): Identification ^ Descriptions. Through Historical Report, the textbook author clearly uses historical facts, court records, observations by some historians, etc. as the basis of his reports. This might be indicated by but not limited to several linguistic features, such as court records, legal convictions, fact, evidence, historian has found, etc. In addition to this, the use of simple past along with its time signals is also to show that the properties, activities, etc. of the subjects under report happened or existed in the old time rather than in the present.

Regardless of its little occurrence, Challenge genre is entirely identical to Coffin $(1997 ; 2006)$ : Challenged Position ${ }^{\wedge}$ Rebuttal Arguments ${ }^{\wedge}$ Anti-Thesis. It is also considered quite unique in the way that the Anti-thesis is generated through synthesizing the challenged claim with another idea. In other words, the generated alternative is not entirely new nor contradicting to the given Position. It is, instead, 
a marriage of the Position under challenge and a new idea. It presents an important picture of how reasoning is positioned within Islam. Reasoning plays central role within the intellectual tradition of Ushul Fiqh. Along with Qur'an, Sunna, and Ijma', reasoning serves as "the foundations of all law in Islamic Jurisprudence" (El Fadl, 2013, p.9).

Table 7 proposes three new genres uncovered within the Islamic Law. Their social purposes are quite or completely different from the recognized genres in the analysis frameworks. Their structures are considered potential because they can consist of stages that can be obligatory and optional but may not be limited to the ones presented below.

Table 7. New genres and their structures in the English language textbook of Islamic law

\begin{tabular}{llcc}
\hline \multicolumn{1}{c}{ Genres } & \multicolumn{1}{c}{ Potential Structures } & Total & $\%$ \\
Preview & Background $\wedge$ Preview Details & 5 & 4.1 \\
Historical Comparative Report & Categorization $^{\wedge}$ Comparisons & 4 & 3.3 \\
Historical Categorizing Report & Categorization $\wedge$ Categories & 2 & 1.6 \\
\hline
\end{tabular}

Preview is the first new genre identified. Its main purpose is to give the readers a general view of the present chapter which is in coverage. Most of its emergences are in the beginning section of the textbook chapters. However, it does not always appear in every chapter, hence, its low percentage of occurrence: 4.1\%. Its potential structure is Background ${ }^{\wedge}$ Previewing Details. Background is a contextual stage giving the readers factual or historical information toward the main theme(s) of the current chapter that are in focus. However, it may be regarded elective since it is not always found. It usually uses simple past or past perfect, and several wordings, such as historical entities and terms but may not be limited to those presented in the following excerpt.

"The Ottomans, the longest-ruling dynasty in Islam, governed vast territories extending from

Arabia to Eastern Europe to North Africa. The history and practices of the Empire are documented in modern scholarship more extensively...." (ILC6S1).

$$
\mathrm{IL}=\text { Islamic Law } \quad \mathrm{C}=\text { Chapter } \quad \mathrm{S}=\text { Section }
$$

The next stage, Previewing Details, provides a brief view of the main theme or sub-themes that is about to be covered in the present chapter. In all of its occurrences, it is always unfolded and even sometimes repeatedly emerges. Therefore, its presence can be considered obligatory. The following excerpt exemplifies a previewing paragraph. The words in bold can be signaling lexical items of the stage.

"With the background provided in the previous chapter, we now turn to discuss how the class of legists perpetuated itself. The story of this chapter is that of the transformation of legal scholarship" (ILC4S1).

The second newly derived genre is Historical Comparative Report. Its social purpose is quite different from that of Derewianka and Jones' Comparative Report (2012). There are two differences. The first difference is the time domain. The new genre only deals with the entities existing in the historical period rather than in the modern days as in Comparative Report. Therefore, this new genre is proposed more appropriately to be put under the genre family of History rather than the Report one. Secondly, the social purpose of this genre turns out to be dissimilar to Derewianka and Jones (2012). The genre is to entirely deal with any distinctions rather than commonalities possessed by at least the two historical subjects under the scrutiny. However, scrutinizing the entities that existed in the past and how they were different from one to another is certainly more difficult than that of the present ones mainly because things are subject to change across time and space. Within all of its emergences, two 
stages always occur to construct this genre: Categorization and Comparison. The opening stage, Categorization, introduces two things that are in comparison. Given its frequent occurrences and its key function, it is compulsory.

"Indeed, as it came to pass, the standard reference of the technical term madhhab was to the doctrinal school, which featured several characteristics lacking in its personal counterpart" (ILC3S1).

It is then followed by Comparison stage which examines the differences of the given things. It is always repeatedly unfolded depending on the number of the aspects of the differences. The bold words signal the key ideas of the excerpt to show how the stage is presented.

First, the personal school comprised the substantive legal doctrine of a single leading jurist.....The doctrinal school, on the other hand, possessed a cumulative doctrine of substantive law in which..In other words, the doctrinal school was a collective and authoritative entity, whereas the personal school remained limited to the individual doctrine of a single jurist (ILC3S1).

Therefore, its existence is important and obligatory which seems to indicate that those things have more differences than similarities. Thus, they deserve to be categorized differently.

Historical Categorizing Report is the next newly identified one in this Islamic legal discourse analysis. This genre is constructed by two specific stages: Categorization and Category. Categorization is initial stage and is considered mandatory which is to classify certain entities that existed in the past by paying attention to a particular set of criteria. This stage may consist of 1) a brief introduction about the entities that will be elaborated, 2) a specific criterion by which the entities are categorized into several classes, and 3) an outline of the classes or group as a result of the classification. The Category characterizes or describes the features that are owned by the entities in the past. Similar to the common middle stages in the given genre framework, its number must logically depend on how many classes or groups derived from the given classification. Thus, this stage tends to be recursive.

Research question 2: what are genres and their generic structures in the English language textbook of Jurisprudence used in UIN-SU?

Table 8 sums up the 14 genre types unfolded within the Jurisprudence textbook along with their structures which have been well recognized in the frameworks.

Table 8. The recognized genres and their generic structures within the English language textbook of jurisprudence

\begin{tabular}{|c|c|c|c|c|}
\hline No & Genres & Generic Structures & Total & $\%$ \\
\hline 1 & Descriptive Report & Classification $^{\wedge}$ Descriptions & 43 & 38 \\
\hline 2 & Classifying Report & Classification $^{\wedge}$ Types & 17 & 15 \\
\hline 3 & Challenge & Challenged Position ${ }^{\wedge}$ Rebuttal Argument & 10 & 8.8 \\
\hline 4 & Exposition & Thesis $\wedge$ Arguments & 10 & 8.8 \\
\hline 5 & Discussion & Issue $\wedge$ Perspectives & 7 & 6.1 \\
\hline 6 & Comparative Report & Classification $^{\wedge}$ Descriptions & 6 & 5.2 \\
\hline 7 & Factorial Explanation & Phenomenon Identification ${ }^{\wedge}$ Factors & 3 & 2.6 \\
\hline 8 & Causal Explanation & Phenomenon Identification ${ }^{\wedge}$ Explanation & 3 & 2.6 \\
\hline 9 & Period Studies & Period Identification $\wedge$ Period Descriptions & 3 & 2.6 \\
\hline 11 & Biography & Person Identification $\wedge$ Episodes & 3 & 2.6 \\
\hline 12 & Conditional Explanation & Phenomenon Identification ${ }^{\wedge}$ Conditions & 1 & 0.9 \\
\hline 13 & Theoretical Explanation & Statement of Theory $\wedge$ Elaborations & 1 & 0.9 \\
\hline 14 & Compositional Report & Classification $\wedge$ Components & 1 & 0.9 \\
\hline
\end{tabular}

Descriptive Report is the most prominent one emerging in the Jurisprudence textbook. Table 8 shows its percentage discrepancy from the other genres by the rank is far enough that encompasses $43 \%$ of the total genres. Given that the genre is a typical Report, its prominence seems consistent with the Sydney 
School's claim that Report genres are the major genres in science textbooks (Martin, 1990, \& Shea, 1988 as cited in Veel, 1997). The most configuration of this genre is identical to Martin and Rose (2008) in the way that two fundamental stages always occur: Classification ${ }^{\wedge}$ Description. In Martin and Rose (2008), Rose (2012), and Derewianka and Jones (2012), Classification stage always constitutes all kinds of the genres. It might be the most notable feature of all the Report genres. At a broader standpoint, its crucial mechanism is shown through its key task: to sort any objects under study into particular kinds.

Challenge is the third most dominant genre in the given textbook. The way how the genre is configured is slightly different from the selected framework (Coffin, 1997; 2006) in the way that an ending stage, Anti-Thesis, does not exist. Thus, the genre is simply made up by the two fundamental stages: Challenged Position ^ Rebuttal Argument. Its primary purpose, however, is found to have an agreement with Coffin $(1997 ; 2006)$ : to present how particular existing theories in discipline of Law (proposed by particular scholars) are criticized and rejected by other scholars. The absence of AntiThesis within the entire analysis of the textbook could indicate that the textbook author simply intends to present to the readers that discursive formations of any legal theories, models, approaches, and claims are both dynamic and complex. Once the theories were generated, proposed, and then became established within the given field, they could not be long-standing or taken for granted to be entirely flawless. Other theories, claims, or approaches (proposed by different scholars) could come up, and then challenge and criticize them. How dynamic the arguing practices actually are in Law as a discipline at large and as a legal tradition could be apparent through the middle stage: Rebuttal Argument. In it, the positions under challenge and their opponents are struggling in the way that the arguments supporting the position are consecutively followed by the arguments against it.

Table 9 proposes three new genres in the Jurisprudence mainly because their purposes are sufficiently or entirely different from the analysis frameworks. Without this effort, the given data would remain unclassified and unexplainable in terms of their uniqueness and particular novelty. Therefore, genres in Table 9 could be considered new in this study: Responsive Explanation, Gradual Explanation, and Preview. Nevertheless, their structures are considered potential since they consist of stages that can be obligatory and optional but may not be limited to those presented below.

Table 9. New genres and their potential structures in the English language textbook of jurisprudence

\begin{tabular}{llcc}
\hline \multicolumn{1}{c}{ Genres } & \multicolumn{1}{c}{ Potential Structures } & Total & $\%$ \\
Responsive Explanation & Phenomenon Identification $^{\wedge}$ Response & 4 & 3.5 \\
Gradual Explanation & Background $\wedge$ Phenomenon Identification $\wedge$ Grades & 1 & 0.9 \\
Preview & Preview Details & 1 & 0.9 \\
\hline
\end{tabular}

The first newly derived genre is a new type of Explanation genres. Although its emergence is not high: $3.5 \%$, the repeated data show that this genre contains different features from the existing genre: Causal Explanation (Veel, 1997) in terms of its purpose and the stage functions through which the main purpose has to be achieved. It is classified to be different since the data show that in the beginning paragraph of the passages, there are usually situations that have a particular tendency to be considered as problem. Therefore, the given phenomena can be considered problematic. Since the phenomena invite a particular concern, they demand any responses to handle, reduce, or solve them. Thus, this genre usually moves through two stages: Phenomenon Identification and Response. Phenomenon Identification introduces a problematic phenomenon which needs to be considered and solved. It usually addresses difficulties, questions or any situations related to particular concepts, terms, or theories that can be regarded as problem. Then, they are responded or solved in the next stage: Response. The concept 
of problem may be signaled by any possible lexical items: difficulty, problem, question, etc. The excerpt below exemplifies the Phenomenon Identification.

"Another problem for Classical Utilitarianism is the question of how to determine accurately exactly what people desire under a given situation. It is therefore difficult to decide upon what measures to take..." (JC5S21).

$\mathrm{J}=$ Jurisprudence $\quad \mathrm{C}=$ Chapter $\quad \mathrm{S}=$ Section

Response explains any necessary approaches responding to or solving the difficulties, problems, etc. introduced in the initial concepts, terms, or theories. Following Hoey's argument in his elaboration of problem-solution pattern (2001), it is labelled as Response rather than Solution. The following legal excerpt displays the stage.

"EAL proposes an approach to the problem which reduces people's desires to economic units. A person's desire for a particular thing may be measured in terms of how much that person..." (JC5S21).

The second new genre is Gradual Explanation which may look similar to Cyclical Explanation (Derewianka \& Jones, 2012). However, its difference lies in its social purpose which is to explain particular phenomena that happened in linear and gradual way rather than the cyclical one since the phenomena have encountered a particular escalation. Within its occurrence, two key stages construct the genre: Phenomenon Identification and Grade. Likewise, the majority of Explanation genres, Phenomenon Identification also introduces a particular phenomenon and then it outlines several gradual phases through which the phenomenon happened. The phases are then explained through the next stage: Grade. Given that the phase is always multiple, its recursivity is certain and necessary. As found in one excerpt, law is explained to encounter development through three gradual phases: charismatic, traditional, and rational. The idea of gradual here is understood when the current phase (Grade 1) is denied or changed because the given entity takes another form in the next stages, Grade 2 until Grade 3. The last newly derived genre is Preview. Its social purpose is to give readers a general view of the current chapter which will be covered. Therefore, it is found in the opening section of the textbook chapters. The only incidence shows that it is only constituted by one stage, Previewing Details. The description of the stage is the same as that in the Islamic Law one.

Research questions 3: what are the similarities and differences of the genres and the generic structures used in the textbook of Islamic Law and those of Jurisprudence?

Table 10. comparison and contrast of the overall genres and their structures found in both of the english language textbook of islamic law and those of jurisprudence

\begin{tabular}{clcc}
\hline No. & \multicolumn{1}{c}{ Genres } & Islamic Law & Jurisprudence \\
1 & Historical Report & V & X \\
2 & Causal Explanation & V & V \\
3 & Historical Account & V & X \\
4 & Factorial Explanation & V & V \\
5 & Descriptive Report & V & V \\
6 & Preview & V & V \\
7 & Classifying Report & V & V \\
8 & Historical Comparative Report & V & X \\
9 & Sequential Explanation & V & X \\
10 & Consequential Explanation & V & X \\
11 & Exposition & $\mathrm{V}$ & V \\
12 & Comparative Report & $\mathrm{V}$ & V \\
13 & Historical Categorizing Report & $\mathrm{V}$ & $\mathrm{X}$ \\
14 & Conditional Explanation & $\mathrm{V}$ & $\mathrm{V}$ \\
15 & Discussion & $\mathrm{V}$ & $\mathrm{V}$ \\
\hline
\end{tabular}




\begin{tabular}{llcc}
\hline 16 & Theoretical Explanation & $\mathrm{V}$ & $\mathrm{V}$ \\
17 & Challenge & $\mathrm{V}$ & $\mathrm{V}$ \\
18 & Biography & $\mathrm{V}$ & $\mathrm{V}$ \\
19 & Compositional Report & $\mathrm{X}$ & $\mathrm{V}$ \\
20 & Gradual Explanation & $\mathrm{X}$ & $\mathrm{V}$ \\
21 & Period Studies & $\mathrm{X}$ & $\mathrm{V}$ \\
22 & Responsive Explanation & $\mathrm{X}$ & $\mathrm{V}$ \\
\hline V=available & & \\
$\mathrm{X}=$ not available & &
\end{tabular}

The similarities between the two legal textbooks can be summarized in several aspects. The first similarity is the emergence of Report genres. In the Jurisprudence, this genre family is the most dominant with more than 50 percent of the overall genres. On the other hand, within its counterpart, although Report genres are not the dominant ones, they are not the least ones either. They make up more than ten percent of the total ones. This degree of dominance shows a consistence with SFL scholars' claim that Report genres are popular in science textbooks (Martin, 1990, \& Shea, 1998 as cited in Veel, 1997). The variations of the genre types and their configurations more or less are similar. Descriptive Report, Classifying Report, and Comparative Report are common within the textbooks, and their generic configurations between the textbooks are also similar. The consistent occurrence of Report genres across the books seems to affirm that classifying practice has "a role in every science" (Okasha, 2002, p.103). Scientists do classifications of the objects that they are studying. They classify countless things according to the episteme of their disciplines. Therefore, the presence of this kind of classifying-oriented genres within the two kinds of legal textbooks is considered to tell the legal students about the episteme of their discipline in order that they are aware of subject matters that they need to pay attention to and study about. The disciplinary matters are certainly wide and various. The matters described across the two textbooks could be both similar and different ideologically. As for the discipline of Islamic Law, they cover but might not be limited to the legal apparatuses, the ideological texts transmissions, legal pluralism, and reasoning. On the other hand, those in its counterpart are any important notions and concepts (norms, policy, sanctions, justice, morality, etc.), any categories of key subject matters (rules, principles of justice, liberty, etc.), any key philosophical approaches to the discipline (realism, formalism, positivism, materialism, utilitarianism, etc.), and other matters.

Second, Argument genres are found in both of the legal textbooks that encompass three sub-genres: Exposition, Discussion, and Challenge. Yet, their percentages are more in the Jurisprudence (23.7\%) than in its counterpart (5.7\%). This discrepancy could be due to the ideological emphasis rather than merely any logical reason. The present analytical deconstruction implies that the presence of Argument genres has two key purposes. Firstly, it is to persuade and argue for the importance of any subject matters within the two kinds of Law: Islamic Law and the Jurisprudence. The purpose is intended particularly to the Law-majoring students as the main textbooks' readers. It seems a prerequisite to anyone who are about to enter the disciplinary community of Law in order to accept the presented ideologies, principles, legal doctrines, etc. The epistemological entities of the field, according to Kuhn (1996), are important to be taken for granted rather than to be examined in terms of their faculty, sufficiency, generality, and validity since they are consensus within the community and considered proved to be effective and fundamental in understanding and handling countless events, cases, or problems beforehand. Therefore, any members of the community, regardless of who they are, seem obliged and bound to think and act on the basis of the epistemological entities. This persuasive purpose is considered to be achieved primarily by the genre resource of Exposition. Interestingly, all of the evidences show that the unfolded Exposition has entirely identical configuration within the two textbooks where any claims or judgements are initially put forward in the first place (through the Thesis) and then it is immediately followed by any reasoning (in the Argument). This simple and more straightforward structure of logic might be more promoted to the students because it looks more easily for them to follow in structuring their arguments 
particularly in speech events like classroom discussions and debates. Durant and Leung (2016) argued for the importance of language in Law due to the absorption of rhetorical tradition into legal advocacy. This is also supported by the interviewed specialist who emphasizes that the ability to argue is important for the students particularly in their career later while they are practising law. The second purpose is to present how complex and dynamic the discursive formations are within the discipline regardless of the ideology to which it is oriented. This can be explained by Okasha (2002) through the so-called context of discovery where he defines it as "the actual historical process by which a scientist arrives at a given theory" (p.79). The present evidences show that after the ideas, claims, or theories are proposed (by a scientist), they are scrutinized and criticized by other scientist(s) with regard to their own clarity, problematic, sufficiency, etc. At this extent, the given ideas encounter a struggle within themselves (claimed by Hegel as cited in Chinhengo, 2002). Thus, the complex and dynamic processes of the disciplinary discovery are aimed to be simplified through the simple structure of the genres resource of Discussion and Challenge in order that the students can learn them more easily. This kind of manipulation, Bernstein (1990) argued, is important practices of pedagogical discourse to give students access to their field.

Although the two books are under the same discipline of Law, they turn out to have a few differences. History genres surprisingly is very frequent in the Islamic Law (51\%) compared to its counterpart $(5.3 \%)$. This large discrepancy could be primarily due to but not limited to the context of ideology. The presented ideology from which the Islamic Law begun as legal practices and then came into existence as a discipline had encountered long historical periods. Therefore, it seems paramount for the Islamic Law textbook author to chronicle the story of the context of the disciplinary discovery (Okasha, 2002) and that of complex discursive formations of the discipline (Foucault, 1972). This genre family encompasses the five types of History genres: Historical Report, Historical Account, Historical Categorizing Report, Historical Comparative Report, and Biography. An important task done through the genres is considered as organizing historical information. This could mean that constructing a body of historical knowledge which embodies historical matters (events, entities, epistemes, discipline apparatuses, discursive practices, etc.) is considered to have disciplinary significance. This is affirmed by the textbook author that "The first half of the book is devoted to a discussion of Islamic law in its pre-modern natural habitat" (Hallaq, 2009) covering Chapter 1 until Chapter 6 where most of the History genres unfolded. The disciplinary significance tends to be "ideological rather than logical" (Coffin, 1997). Decision on what is considered important and the otherwise might not be value-free. This could be due to a dual role of the textbook author who simultaneously enacts as a historian as well as an Islamic Law scholar. The task can be mainly achieved through the genre resources of History. The importance of history in studying Law is confirmed by the Legal specialist of UIN-SU who explained that law students, indeed, need to learn history. Law changes subject to particular historical effects. The specialist informant affirmed that one cannot formulate any regulation without historical effects of the actions or the matters regulated. One action, which had no legal consequence in the past, may have a legal consequence in this present time. In the context of Islamic ideology, the historical effects can be learned through the context of reasons why the divine texts were revealed which is also known as asbabun nuzul. The final point that could be drawn is that History genre family is an important device within the pedagogical discourse to facilitate students so that they are aware of what had been done and what had ever existed in the past disciplinary account of Islamic Law.

The explanations of the legal historical consequence can be presented not only through the History genres but also through Explanation genres. A number of genre variations are found within the Legal textbooks. In the Islamic Jurisprudence alone, they encompass $35.5 \%$ which can be considered quite high. Their variations across the textbooks also include the new genres; namely, 1) Causal Explanation, 2) Factorial Explanation, 3) Responsive Explanation, 4) Sequential Explanation, 5) Consequential 
Explanation, 6) Conditional Explanation, 7) Theoretical Explanation, 8) and Gradual Explanation. Each of them has its own social purpose and mechanism. This finding seems to indicate that causation is also crucial in law in general which is not only law as a field of study but also law as a practice and as a system.

\section{Conclusion}

The present investigation has attempted to extend the genre frameworks on the basis of SFL traditions commonly used in the primary and secondary schools to the higher educational level or university in Indonesian context. Two legal textbooks in the English Language at Universitas Islam Negeri Sumatera Utara (UIN-SU) in Indonesia are used as the data of the study to be deconstructed in order that the genres and the generic structures of the texts within the textbooks are classified and configured. Based on the five main SFL-genre frameworks, 18 genre types including three new ones under four main genre families are found within the Islamic Law textbook. History genres are identified as the most frequent ones followed by Explanation, Report, and Argument genres. On the other hand, 16 genres including three new ones belonging to four key genre families are found in the Islamic Law's counterpart. Report genres are the most frequent ones followed by Argument, Explanation, and History ones.

The discrepancies of the generated findings throughout the legal textbooks could be considered as one of the results of both ideological discrepancies that formed and determined the epistemes of the disciplines and the textbooks basis, and also distinctions of the disciplinary resources from which the legal disciplines are oriented. One of the fundamental discrepancies of both Laws is the way how those matters should be viewed from the basis of ideological orientation, paradigms, or the agreed principles within the discipline. On the other hand, both the Islamic Law and Jurisprudence have many commonalities of subject matters because they in fact mainly draw attention of legal scholars. For Islamic legal thinkers, the legal problems intricacies are important in the way that how they must be responded to rigidly adhering to the Islamic Law presented in the historical ideological texts (Al-Qur'an and Al-Hadith) as the basis of Islamic law making because certain problems can be more intricated over time. The genre variations presented in the given findings are the logical results of the various subject matters throughout both the Islamic Law and Jurisprudence textbooks that learners need to meet and read during their study. Therefore, they are required to have formal schema (background knowledge about genres and their structures) before they read the texts. Through this strategy, learners' formal schema can facilitate their reading comprehension (Uso-Juan \& Flor, 2006; Leon \& Carretero, 1995).

\section{Ethics committee approval}

The authors confirm that ethical approval was not required for this study. (Date of Confirmation: 18.06.2020)

\section{Acknowledgement}

This research was funded by Suranaree University of Technology, Thailand through SUT-ASEAN Scholarship. 


\section{References}

Bernstein, B. (1990). Class, Codes and Control: The Structuring of Pedagogic Discourse. London: Routledge.

Carrell, P. L. (1985). Facilitating ESL Reading by Teaching Text Structure. TESOL Quarterly, 19(4), 727-752. https://doi.org/10.2307/3586673

Carrell, P. L. (1992). Awareness of Text Structure: Effects on Recall. Language Learning, 42(1), 1-18. https://doi.org/10.2307/747572

Chinhengo, A. M. (2000). Essential Jurisprudence ( $2^{\text {nd }}$ ed.). London: Cavendish Publishing Limited

Christie, F., \& Derewianka, B. (2010). School Discourse: Learning to Write Across the Years of Schooling. London: Continuum.

Coffin, C. (1997). Constructing and Giving Value to the Past: An Investigation into Secondary School History. In F. Christie \& J. R. Martin (Eds.). Genre and Institutions: Social Processes in the Workplace and School (pp. 196-230). London: Continuum.

Coffin, C. (2006). Historical Discourse: The Language of Time, Cause and Evaluation. London: Continuum.

Dalimunte, A. A., \& Pramoolsook, I. (2020). Genres Classification and Generic Structures in the English Language Textbooks of Economics and Islamic Economics in an Indonesian University. LEARN Journal, 13(1), 1-19. https://www.tci-thaijo.org/index.php/LEARN/article/view

Derewianka, B. (1990). Exploring How Texts Work. Maryborough: Australian Print Group.

Derewianka, B., \& Jones, P. (2012). Teaching Language in Context. Victoria: Oxford University Press.

Dickson, S. (1999). Integrating Reading and Writing to Teach Compare-Contrast Text Structure: A Research-based Methodology. Reading and Writing Quarterly, 14, 49-79. https://doi.org/10.1080/105735699278297

Durant, A., \& Leung, J. (2016). Language and Law. New York: Routledge.

El-Fadl, K. A. (2013). The Shari'ah. In John L. E. \& Shahin E. E. (Eds.) The Oxford Handbook of Islam and Politics (pp.7-26). Oxford: Oxford University Press.

Elliott, D. L., and Woodward, A. (Eds.). (1990). Textbooks and Schooling in the United States (89th Yearbook of the National Society for the Study of Education). Chicago: National Society for the Study of Education.

Foucault, M. (1972). The Archaeology of Knowledge and the Discourse on Language. New York: Tavistock Publications Limited.

Hallaq, W. B. (2009). An Introduction to Islamic Law. Cambridge: Cambridge University Press.

Hoey, M. (2001). Textual Interaction: An Introduction to Written Discourse Analysis. London: Routledge.

Hyland, K. (2000). Disciplinary Discourses: Social Interactions in Academic Writing. Harlow, UK: Pearson Education.

Kuhn, S.T. (1996). The Structure of Scientific Revolutions ( $3^{\text {rd }}$ ed.) Chicago: University of Chicago Press. 
Lee, C. D., \& Spratley, A. (2010). Reading in the Disciplines: The Challenges of Adolescent Literacy. New York: Carnegie Corporation of New York.

Leon, J. A., \& Carretero, M. (1995). Intervention in Comprehension and Memory Strategies: Knowledge and Use of Text Structure. Learning and Instruction, 5(3), 203-20. https://doi.org/10.1016/09594752(95)00011-Q

Martin, J. R. (1990). Factual Writing: Exploring and Challenging Social Reality (2 ${ }^{\text {nd }}$ ed.). Oxford: Oxford University Press.

Martin, J. R. (1993). Literacy in Science: Learning to Handle Text as Technology. In M. A. K. Halliday \& J. R. Martin (Eds.). Writing Science: Literacy and Discursive Power (pp.166-202). London: Falmer Press.

Martin, J. R., \& Rose, D. (2008). Genre Relations: Mapping Culture. London: Equinox.

McGee, L. M. (1982). Awareness of Text Structure: Effects on Children's Recall of Expository Text. Reading Research Quarterly, 17(4), 581-590. https://doi.org/10.2307/747572

Meyer, B. J. F., (1975). Identification of the Structure of Prose and its Implications for the Study of Reading and Memory. Journal of Reading Behavior, 7(1), 7-47.

Okasha, S. (2002). Philosophy of Science: A Very Short Introduction. New York: Oxford University Press.

Orwin, R. G. (1994). Evaluating coding decisions. In: H. Cooper \& L.V. Hedges (Eds). The Handbook of Research Synthesis (pp.177-200). New York: Russell Sage Foundation.

Parodi, G. (2010). The Rhetorical Organization of the Textbook Genre Across Disciplines: A 'Colonyin-Loops'? Discourse Studies, 12(2), 195-222. https://doi.org/10.1177/1461445609356500

Paul, R. \& Elder, L. (2006). Critical thinking: learn the tools, the best thinkers use. USA: Pearson Education, Inc.

Richgels, D. J., McGee, L. M., Lomax, R. G., \& Sheard, C. (1987). Awareness of Four Text Structures: Effects on Recall of Expository Text. Reading Research Quarterly, 22(2), 177-196.

Rose, D. (2012). Genre in the Sydney School. In J. Gee \& M. Handford (Eds.). The Routledge Handbook of Discourse Analysis (pp. 209-225). London: Routledge.

Stern, L., \& Roseman, J. E. (2004). Can Middle School Science Textbooks Help Students Learn Important Ideas? Findings from Project 2061's Curriculum Evaluation Study: Life Science. Journal of Research in Science Teaching, 41(6), 538-568. https://doi.org/10.1002/tea.20019

Strong, R. W., Silver, H. F., Perini, M. J., \& Tuculescu, G. M. (2002). Reading for Academic Success: Powerful Strategies for Struggling, Average, and Advanced Readers, Grades 7-12. California: Corwin Press, Inc. https://eric.ed.gov/?id=ED465158

United Nations Educational, Scientific and Cultural Organization (UNESCO). (2009). Promoting Gender Equality Through Textbook: A Methodological Guide. France: United Nations Educational, Scientific and Cultural Organization.

Unsworth, L. C., (1995). How and Why Recontextualizing Science Explanations in School Science Books (Unpublished Doctoral Dissertation). University of Sydney, Sydney.

Uso-Juan, E., \& Flor, A. M. (Eds.). (2006). Current Trends in the Development and Teaching of the Four Language Skills. Berlin: Mouton de Gruyter. 
Veel, R. (1997). Learning How to Mean-Scientifically Speaking: Apprenticeship into Scientific Discourse in the Secondary School. In F. Christie \& J. Martin (Eds.). Genres and Institutions: Social Processes in the Workplace and School (pp.161-194). London: Continuum.

Zarrati, Z., Nambiar, R. M., \& Maasum, T. N. R. T. M. (2014). The Importance of Text Structure Awareness in Promoting Strategic Reading among EFL Readers. Procedia-Social and Behavioral Sciences, 118, 537-544. http://doi.org/10.1016/j.sbspro.2014.02.073

Zhang, X. (2008). The Effects of Formal Schema on Reading Comprehension: An Experiment with Chinese EFL Readers. Computational Linguistics and Chinese Language Processing, 13(2), 197214.

\section{Endonezya'daki bir üniversitede İslam hukuku ve içtihat ders kitaplarında sistemik işlevsel dilbilim-yasal türler ve bunların konfigürasyonları}

\section{$\ddot{\mathbf{O z}}$}

Ders kitaplarının akademik, pedagojik ve bilimsel dünyada İngilizce dilinde büyük önemi tartı̧masızdır. Disiplinler arası bütünsel bilgi edinmek Endonezya'daki İslam hukuku öğrencileri için büyük önem taşımaktadır. Ancak, Endonezyalı öğrencilerin İngilizce okuma yeterliliği sorunludur. Mevcut araştırma, biçim türlerini tanımlamak ve onları çoğunlukla yapılandırıldığı kalıplar aracılı̆ııla ortaya çıkarmaktır. Çalışmanın verileri, Endonezya'daki Universitas Islam Negeri Sumatera Utara'da öğretim kaynağı olarak kullanılan bir İslam hukuku ders kitabı ve bir içtihat ders kitabıdır. Analiz için beş ana Sistemik işlevsel dilbilim tabanlı tür çerçevesine dayanarak, İslam hukuku ders kitabından elde edilen bulgular, dört tür ailesi altında önerilen üç tür de dahil olmak üzere 18 tür türünü gösterdi; bunlardan en sık kullanılanları Tarih türleri olan Açıklama, Rapor ve Bağımsız değişken türleridir. Öte yandan, rapor türlerinin en sık olduğu içtihatta, dört tür ailesine ait üç yeni olmak üzere 16 tür türü belirlendi, ardından Argüman, Açıklama ve Tarih türleri geldi. İki hukuk ders kitabı arasındaki bulguların ortak yönleri ve tutarsızlıkları, ideolojik farklılıkların mantıksal sonuçları ve hukuk disiplininin yöneldiği kaynak yönleri olarak kabul edilmektedir. Araştırmanın bulguları, öğrencilere hem İngilizce hem de hukuk öğretmenleri tarafından ne yazık ki ihmal edilen hukuki İngilizce metinleri okuma öğretimini kolaylaştıracak şekilde tasarlamada faydalı olacaktır.

Anahtar Sözcükler: sistemik işlevsel dilbilim; tür; ders kitabı; islam hukuku; içtihat

\section{AUTHOR BIODATA}

Issra Promoolsook is an assistant professor in applied linguistics and English language teaching at Suranaree University of Technology, Thailand. His research interests include genre and disciplinary discourse analysis and writing for academic and professional purposes. 
Ahmad Amin Dalimunte is an English teacher at Universitas Islam Negeri Sumatera Utara (UIN-SU), Indonesia. He obtained his PhD in English Language Studies at Suranaree University of Technology, Thailand. His research interests include disciplinary discourse and genre analysis, academic reading and writing, and language planning. 